\title{
Effect of Multi-Layer Carbon Fiber Sheet Used for Strengthening Reinforced Concrete Beams
}

\author{
Young-Chan You $^{1{ }^{*}}$, Ki-Sun Choi ${ }^{1)}$, and Keung-Hwan Kim ${ }^{1)}$ \\ ${ }^{1)}$ Building Research Division, Korea Institute of Construction Technology, Korea
}

(Received February 5, 2004; Accepted December 31, 2004)

\begin{abstract}
The purpose of this study is to investigate the flexural strengthening effects of CF(Carbon Fiber) sheet for the full-scale $\mathrm{RC}$ beams with multi-layer $\mathrm{CF}$ sheets. The partial strength reduction factors of $\mathrm{CF}$ sheets are suggested from the full-scale RC beams tests strengthened with multi-layer $\mathrm{CF}$ sheets up to six layers as well as material tests. From the material tensile tests, it was observed that the average tensile strengths of CF sheets per layer are decreased as the number of $\mathrm{CF}$ sheets is increased. Also the steep strength reductions of CF sheets in material test results at rupture are observed compared with the structural tests results for the full-scale RC beams strengthened with multi-layer CF sheets. Finally, the partial strength reduction factors for CF sheets up to six layers are suggested considering the effects of multi-layer and unit weight of CF sheets.
\end{abstract}

Keywords : CF(carbon fiber) sheet, CFRP(carbon fiber reinforced polymer), partial strength reduction factor, design strength, multi-layer

\section{Introduction}

$\mathrm{CF}$ (Carbon Fiber) sheet is considered to be the alternatives to the steel plate due to the high strength, high stiffness, lower weight and the excellent resistance against fatigue. The specified tensile strength provided by the manufacturer is determined on the basis of the reliable strength lower limit $(\mathrm{X}-3 \sigma: \mathrm{X}=$ average tensile strength, $\sigma=$ standard deviation) obtained from the material tests. ${ }^{7,8)}$ Most of these data, however, are based on the test results of 1 layer of CF sheet. Also, some researchers ${ }^{1,2)}$ suggested the partial strength reduction factor for strengthening $\mathrm{RC}$ members with CFS system based on the small-scale model tests. But, in the case of small-scale model tests, the number of $\mathrm{CF}$ sheets is usually limited within 2 layers due to the geometrical restrictions. When the number of $\mathrm{CF}$ sheets becomes 3 or more, the final failure modes of the small-scale member were governed by the debonding of CF sheets or the compression failure of concrete, causing under-estimation of the strengthening effects of CF sheets. ${ }^{5)}$

\footnotetext{
* Corresponding author

E-mail address: ycyou@kict.re.kr

(c)2005 by Korea Concrete Institute
}

On the other hand, CFRP(Carbon Fiber Reinforced Polymer) consists of $\mathrm{CF}$ sheets and the saturating epoxy resin which impregnates and bonds $\mathrm{CF}$ sheets to the concrete. So, the accumulated partial defects of saturating epoxy and irregular arrangement of carbon fiber can cause the reduction of tensile strength of CFRP as the number of CF sheets increases. The objective of this study is to investigate the strength reduction characteristics of multi-layer $\mathrm{CF}$ sheets up to 6 through the full-scale model tests as well as the material tests.

\section{Experimental program}

\subsection{Material tests}

Air-entrained concrete with specified compressive strength of $24 \mathrm{MPa}$ was supplied by a local ready-mix plant. Type I portland cement and $25 \mathrm{~mm}$ nominal maximum size coarse aggregate were used. Compression cylinders measuring $\varphi 100 \times 200 \mathrm{~mm}$ are prepared for each specimen. The material test for high strength $200 \mathrm{~g} / \mathrm{m}^{2}$ and $300 \mathrm{~g} / \mathrm{m}^{2}$ CF sheets produced by domestic manufacturer in Korea were carried out. Tensile properties as well as me- 
chanical properties of CF sheets and epoxy resin were obtained. The material tests for the multi-layer CF sheets were carried out according to the standard test procedure of JIS $\mathrm{K} 7073^{6)}$ using U.T.M whose permissible capacity is $50 \mathrm{kN}$. The width and length of tensile test specimen are $12.5 \mathrm{~mm}$ and $200 \mathrm{~mm}$, respectively. Also, GFRP taps with $1.5 \mathrm{~mm}$ thickness were attached at each end of test specimen. Table 1 4 show the test results of the each materials.

Material test specimen of CF sheets ranged from 1 to 5 layers for HS200 and from 1 to 3 layers for HS300. In this study, 'HS' and the number after 'HS' stand for high strength and fiber weight per unit square meters in gram, respectively. The fiber thickness of single layer of HS300 is 1.5 times thicker than that of HS200.

\subsection{Full-scale RC beam tests}

\subsubsection{Test specimen}

The full-scale RC beam specimens were manufactured in order to ensure the sufficient bonding length of CF sheets up to 6 layers. On the other hands, according to the sectional analysis for the rectangular RC beam strengthened

Table 1 Material properties of concrete

\begin{tabular}{c|c|c|c}
\hline Curing age & $\begin{array}{c}\text { Tensile strength } \\
(\mathrm{MPa})\end{array}$ & $\begin{array}{c}\text { Compressive } \\
\text { strength(MPa) }\end{array}$ & $\begin{array}{c}\text { Young's } \\
\text { modulus(GPa) }\end{array}$ \\
\hline \hline 69 days & 3.25 & 35.2 & 28.1 \\
\hline
\end{tabular}

Table 2 Material properties of reinforcing bar

\begin{tabular}{c|c|c|c|c}
\hline $\begin{array}{c}\text { Bar } \\
\text { size }\end{array}$ & $\begin{array}{c}\text { Yield strength } \\
(\mathrm{MPa})\end{array}$ & $\begin{array}{c}\text { Young's } \\
\text { modulus(GPa) }\end{array}$ & $\begin{array}{c}\text { Tensile } \\
\text { strength(MPa) }\end{array}$ & $\begin{array}{c}\text { Elongation } \\
(\%)\end{array}$ \\
\hline \hline D10 & 390.1 & 176 & 562.0 & 28 \\
\hline D19 & 406.1 & 179 & 626.2 & 19 \\
\hline D22 & 361.0 & 171 & 565.8 & 17 \\
\hline
\end{tabular}

Table 3 Material properties of CFRP $\left(t_{c f}=0.111 \mathrm{~mm}\right)$

\begin{tabular}{c|c|c|c}
\hline Classification & $\begin{array}{c}\text { Tensile strength } \\
(\mathrm{MPa})\end{array}$ & $\begin{array}{c}\text { Young's modulus } \\
(\mathrm{GPa})\end{array}$ & $\begin{array}{c}\text { Failure strain } \\
(\%)\end{array}$ \\
\hline \hline Nominal & 3,550 & 235.0 & 1.51 \\
\hline Test & 4,513 & 259.0 & 1.70 \\
\hline
\end{tabular}

Table 4 Material properties of epoxy resin

\begin{tabular}{c|c|c|c|c}
\hline $\begin{array}{c}\text { Classifica- } \\
\text { tion }\end{array}$ & $\begin{array}{c}\text { Compressive } \\
\text { strength(MPa) }\end{array}$ & $\begin{array}{c}\text { Tensile } \\
\text { strength(MPa) }\end{array}$ & $\begin{array}{c}\text { Flexural } \\
\text { strength } \\
\text { (MPa) }\end{array}$ & $\begin{array}{c}\text { Shear } \\
\text { strength } \\
\text { (MPa) }\end{array}$ \\
\hline \hline Nominal & 70.0 & 30.0 & 40.0 & 10.0 \\
\hline Test & 64.7 & 32.0 & 49.0 & 11.0 \\
\hline
\end{tabular}

with more than 3 layers of HS200 CF sheets, the compression failure of concrete at the extreme compressive fiber of concrete preceded the rupture of CF sheets at the extreme tensile fiber of concrete. Consequently, $\mathrm{T}$ beam with effective width of slab were manufactured in the case of the specimen strengthened by 4 or 6 layers of HS200 CF sheets and by 3 layers of HS300 CF sheets in order to provide sufficient compressive block and to prevent the compression failure of the strengthened members.

At all the strengthened specimens, 'U-shape fiber wrap' as shown in Fig. 1 were applied at the nearby loading point which was proved to have the feasibility to prevent the debonding failure of CF sheets caused by the large flexuralshear deformation. ${ }^{5)}$ The details and dimensions of test specimens are shown in Fig. 1 and Table 5.
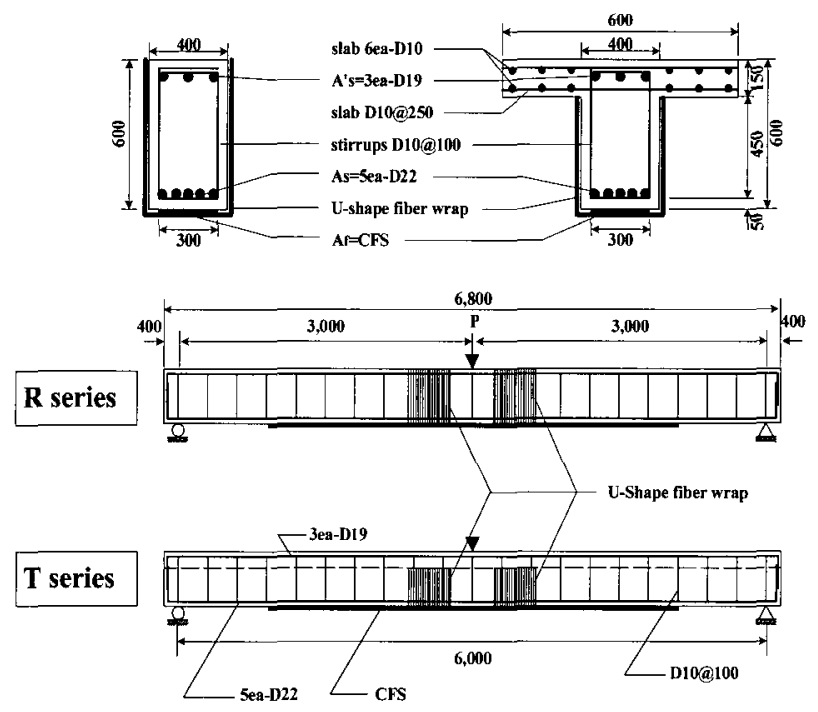

Fig. 1 Details and dimension of typical specimens

Table 5 Details of reinforcing bar and CF sheets

\begin{tabular}{|c|c|c|c|c|}
\hline Specimen & Reinforcement & $\begin{array}{c}\text { Layer } \\
\text { (ply) }\end{array}$ & $\begin{array}{c}\text { Bond } \\
\text { length }(\mathrm{mm})\end{array}$ & Remark \\
\hline RS & \multirow{4}{*}{$\begin{array}{c}\mathrm{A}_{\mathrm{s}}^{\prime}=861 \mathrm{~mm}^{2} \\
\mathrm{~A}_{\mathrm{s}}=1,935 \mathrm{~mm}^{2} \\
\rho / \rho_{\mathrm{b}}=0.3\end{array}$} & - & - & Control \\
\hline RF1-UCS3 & & 1 & 2,000 & HS300 \\
\hline RF2-UCS3 & & 2 & 4,000 & HS300 \\
\hline RF2-B2 & & 2 & 2,700 & HS200 \\
\hline TS & \multirow{4}{*}{$\begin{array}{c}A_{s}^{\prime}=861 \mathrm{~mm}^{2} \\
A_{s}=1,935 \mathrm{~mm}^{2} \\
\rho / \rho_{b}=0.17 .\end{array}$} & - & - & Control \\
\hline TF3-UCS3 & & 3 & 6,000 & HS300 \\
\hline TF4-UCB2 & & 4 & 5,400 & HS200 \\
\hline TF6-UCB2 & & 6 & 6,000 & HS200 \\
\hline
\end{tabular}

$A_{\mathrm{s}}^{\prime}:$ area of top bar

$A_{s}$ : area of bottom bar

$\rho:$ reinforcement ratio

$\rho_{\mathrm{b}}:$ reinforcement ratio at balanced failure 


\subsubsection{Test set-up}

The loading frame at which 1-point load is applied at the center of beam specimen was set-up for the structural test whose permissible capacity is $1000 \mathrm{kN}$ (Fig. 2). As a measuring device, two units of $200 \mathrm{~mm}$ LVDT were settled for the measurement of deflection at mid-span. Ten units of strain gauge type transducer (PI Displacement Transducer) were settled at $60 \mathrm{~mm}$ intervals at central part of the beam to obtain the sectional strain gradient. Two units of WSG(wire strain gauges) were settled on the central part of lower CFS. For the specimen with U-shape fiber wrap, the WSG were attached on the U-wrap along the fiber direction to measure the CF sheets strain. Fig. 4 shows the location of the each measuring apparatus.

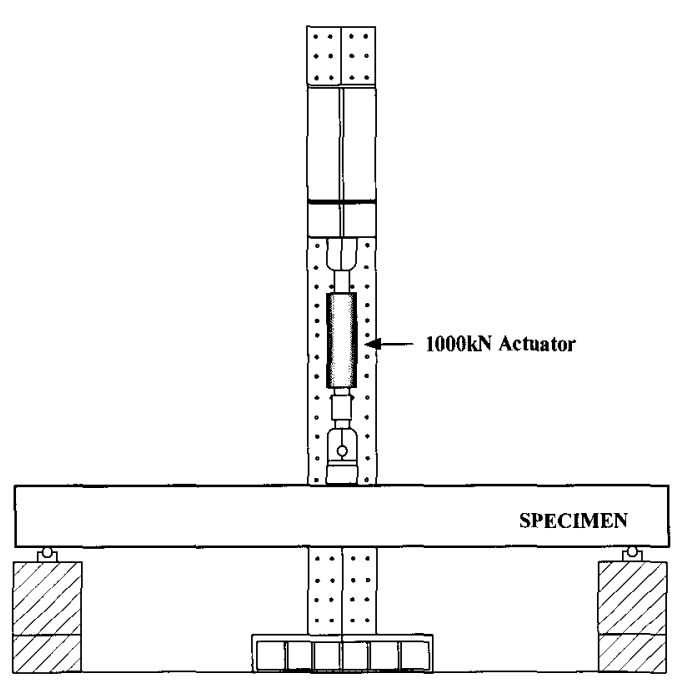

Fig. 2 Specimen test set-up

\section{Test results}

\subsection{Material test results}

Table 6 shows the material tensile test results for HS200 and HS300 CF sheets. As shown in Table 6, it is clear that the tensile strength of CF sheets is decreased as the number of CF sheets is increased in the material test results.

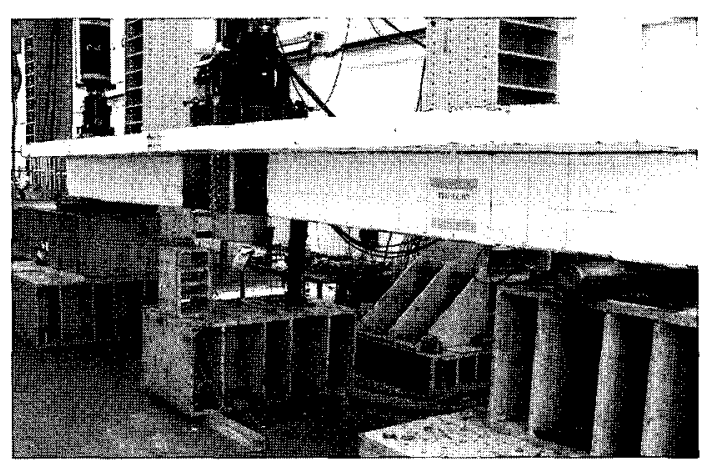

Fig. 3 General view of test set-up

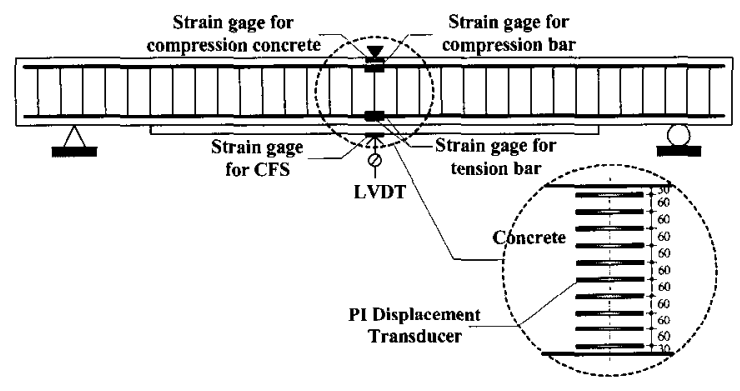

Fig. 4 Location of measurement apparatus

Table 6 Material tensile strength and reliable lower limits

\begin{tabular}{c|c|c|c|c|c|c}
\hline CF Type & Layer & CF THK(mm) & Section Area $\left(\mathrm{mm}^{2}\right)$ & Max. Load(kN) & Tensile Strength(MPa) & X-3 $\sigma_{\mathrm{n}}(\mathrm{MPa})$ \\
\hline \multirow{5}{*}{$200 \mathrm{~g}$} & 1-ply & 0.111 & 1.34 & 6.04 & $4,477(1.00)^{*}$ & 3,954 \\
\cline { 2 - 8 } & 2-ply & 0.222 & 2.70 & 11.03 & $4,072(0.91)^{*}$ & 3,451 \\
\cline { 2 - 8 } & 3-ply & 0.333 & 4.09 & 15.17 & $3,707(0.83)^{*}$ & 3,189 \\
\cline { 2 - 8 } & 4-ply & 0.444 & 5.33 & 19.07 & $3,581(0.80)^{*}$ & 3,124 \\
\cline { 2 - 8 } & 5-ply & 0.555 & 6.95 & 24.83 & $3,572(0.79)^{*}$ & 2,779 \\
\hline \multirow{5}{*}{$300 \mathrm{~g}$} & 1-ply & 0.167 & 2.06 & 8.99 & $4,367(1.00)^{*}$ & 3,533 \\
\cline { 2 - 8 } & 2-ply & 0.334 & 4.11 & 15.62 & $3,803(0.87)^{*}$ & 3,240 \\
\cline { 2 - 8 } & 3-ply & 0.501 & 6.47 & 24.48 & $3,784(0.86)^{*}$ & 3,201 \\
\hline
\end{tabular}

\footnotetext{
* The number in a parenthesis represent the tensile strength ratio of each specimen compared to that of 1-ply specimen

$\mathrm{X}$ : average tensile strength

$\sigma_{\mathrm{n}}:$ standard deviation
} 


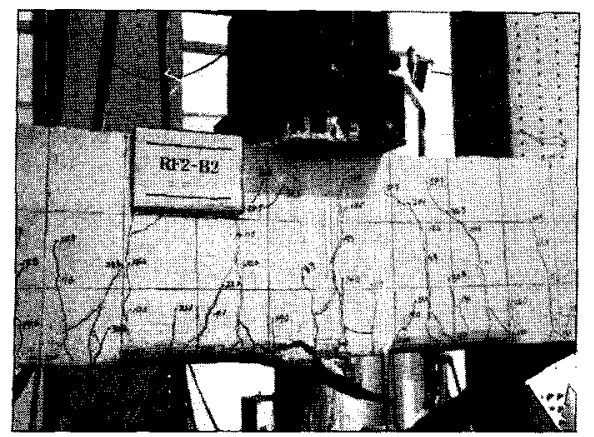

(a) RF2-B2

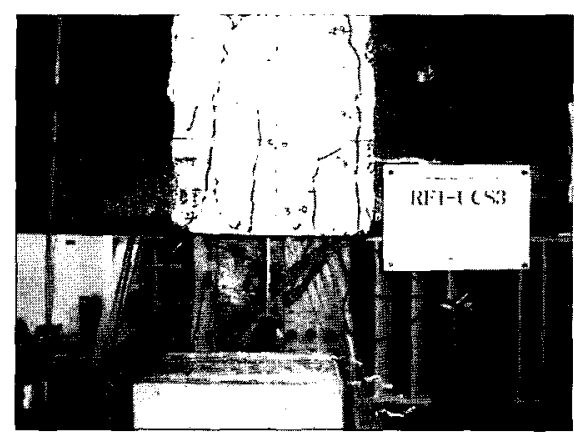

(d) RF1-UCS3

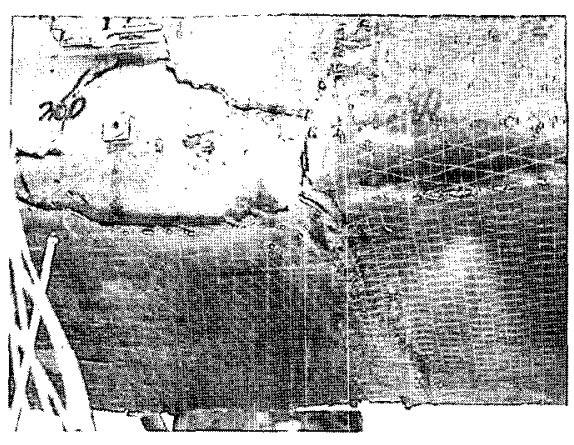

(b) TF4-UCB2

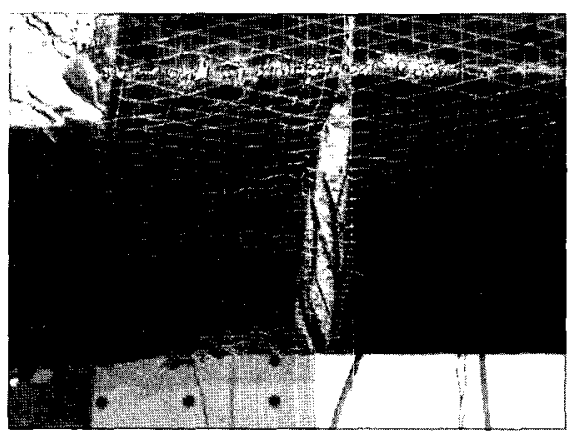

(e) RF2-UCS3

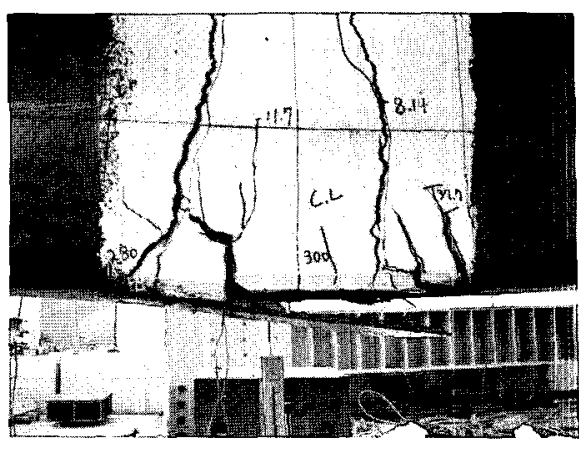

(c) TF6-UCB2

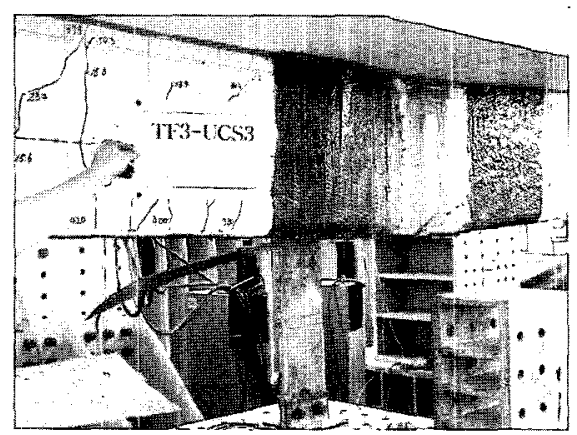

(f) TF3-UCS3

Fig. 5 Final failure pattern : (a) (f) CF sheets rupture

Although all the average tensile strength of CF sheets per layer exceed the nominal tensile strength, the reliable strength lower limit of CF sheets considering large strength deviation of CF sheets, $X-3 \sigma_{n}$, is less than the specified nominal tensile strength as shown in Table 6.

\subsection{Full-scale RC beam test results}

\subsubsection{Failure mode}

Fig. 5 and Table 7 show the final failure modes and the test results of each specimen, respectively. Here, $\Delta \mathrm{P}_{\mathrm{cf}}$ in
Table 7 indicates the difference between the maximum load of strengthened specimens and the yield load of control beam. The failure mode of all the specimen were governed by the rupture of CF sheets regardless of fiber type and the number of layers even though local debonding was observed between concrete and CF sheets after the tensile reinforcements were yielded. But the rupture strain of $\mathrm{CF}$ sheets at each specimen varied from $6,998 \times 10^{-6}$ to $12,395 \times 10^{-6}$, that is $46 \sim 82 \%$ of the specified rupture strain. Fig. 6 represents the load-deflection relationship of each specimen at mid-span.

Table 7 Comparison of calculated and experimental results

\begin{tabular}{|c|c|c|c|c|c|c|c|c|c|c|}
\hline \multirow{2}{*}{ Specimen } & \multicolumn{2}{|c|}{ Yield $\operatorname{load}(\mathrm{kN})$} & \multicolumn{3}{|c|}{ Max. load(kN) } & \multirow{2}{*}{$\begin{array}{l}\Delta \mathrm{P}_{\mathrm{cf}} \\
(\mathrm{kN})\end{array}$} & \multirow{2}{*}{$\begin{array}{c}\delta \\
(\mathrm{mm})\end{array}$} & \multirow{2}{*}{$\begin{array}{c}\varepsilon_{\mathrm{c}} \\
\left(\times 10^{-6}\right)\end{array}$} & \multirow{2}{*}{$\begin{array}{c}\varepsilon_{\mathrm{cf}} \\
\left(\times 10^{-6}\right)\end{array}$} & \multirow{2}{*}{ Failure mode } \\
\hline & $\mathrm{Cal}_{\mathrm{n}}$ & $\operatorname{Exp}$ & $\mathrm{Cal}_{\mathrm{n}}$ & $\mathrm{Cal}_{\mathrm{u}}$ & $\operatorname{Exp}$ & & & & & \\
\hline RS & 252.6 & 284.5 & 264.7 & 299.5 & 312.7 & - & 76.90 & 3,000 & - & Flexural \\
\hline RF1-UCS3 & 261.6 & 269.9 & 327.9 & 356.2 & 340.2 & 55.7 & 50.19 & 2,587 & 12,395 & CF sheet rupture \\
\hline RF2-UCS3 & 270.3 & 277.0 & 390.0 & 416.0 & 372.0 & 87.5 & 56.20 & - & 10,423 & $"$ \\
\hline RF2-B2 & 264.4 & 284.8 & 346.8 & 378.0 & 357.1 & 72.6 & 54.12 & 2,755 & 9,796 & $"$ \\
\hline $\mathrm{TS}$ & 264.6 & 303.8 & 277.8 & 315.2 & 404.7 & - & 16.34 & 843 & - & Flexural \\
\hline TF3-UCS3 & 291.6 & 358.4 & 475.5 & 586.3 & 443.1 & 139.3 & 48.93 & 1,390 & 7,730 & CF sheet rupture \\
\hline TF4-UCB2 & 288.5 & 349.5 & 452.7 & 557.4 & 410.7 & 106.9 & 36.02 & 1,315 & 6,998 & $"$ \\
\hline TF6-UCB2 & 300.6 & 375.4 & 540.9 & 669.1 & 478.5 & 174.7 & 45.72 & 1,666 & 7,436 & $"$ \\
\hline
\end{tabular}

$\mathrm{CaI}_{\mathbf{n}}$ : Nominal yield load

$\mathrm{Cal}_{\mathrm{u}}$ : Nominal ultimate load with actual material strength

$\varepsilon_{\mathrm{c}}$ : Concrete strain at CF sheets rupture (Ultimate state)
$\mathrm{Cal}_{\mathrm{n}}$ : Nominal ultimate load with nominal material strength $\Delta \mathrm{P}_{\mathrm{cf}}$ : Load decrease at $\mathrm{CF}$ sheet rupture

$\varepsilon_{\mathrm{cf}}: \mathrm{CF}$ sheet strain at CF sheet rupture (Ultimate state) 


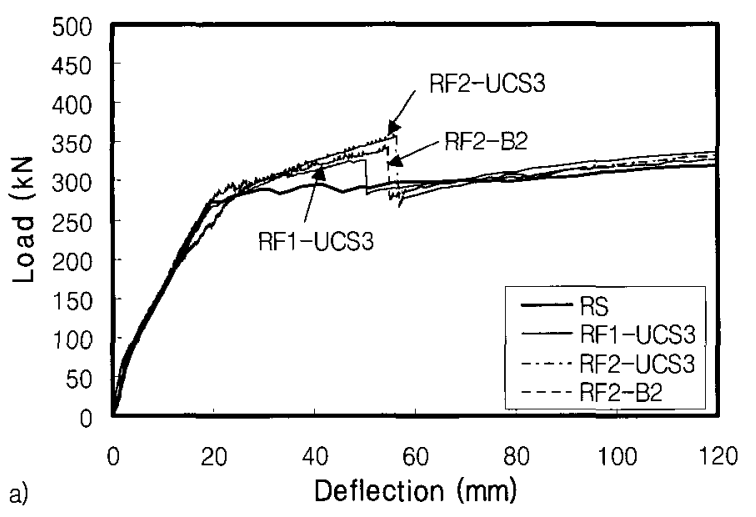

(a) Rectangular section

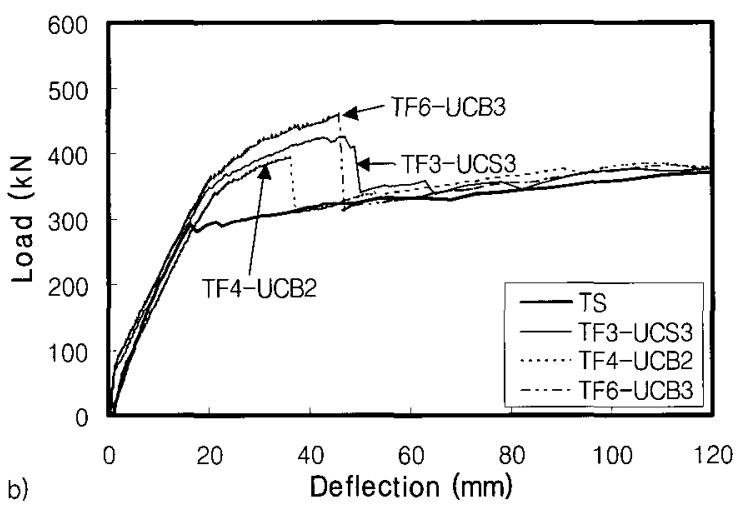

(b) T-section

Fig. 6 Load-deflection curves

\subsubsection{Sectional strain gradient}

Fig. 7 shows the sectional strain gradient obtained from ten units of PI Displacement Transducers which were settled at $60 \mathrm{~mm}$ intervals on the beam web as shown in Fig. 4. The sectional strain distribution appears to be a linear before yielding of reinforcing bar, but strain of reinforcing bar tends to be greater than that of CFS after yielding. It means that some slips are expected to be happened between concrete tensile fiber and CFS. From that point of view, an actual distance from extreme compression fiber to neutral axis is always smaller than that theoretically computed by linear strain distribution, which results in conservative estimations.

\subsubsection{Strengthening effects by CFS}

Previous studies ${ }^{1-4)}$ estimated the strengthening effects of FRP on the basis of the strength increments between the nominal flexural capacity of non-strengthened members by analysis and the maximum flexural capacity of strengthened members by test. But this method has the possibilities to overestimate the strengthening effects by CFS because probable strength increment of RC members was included in the maximum flexural capacity of the strengthened beams.

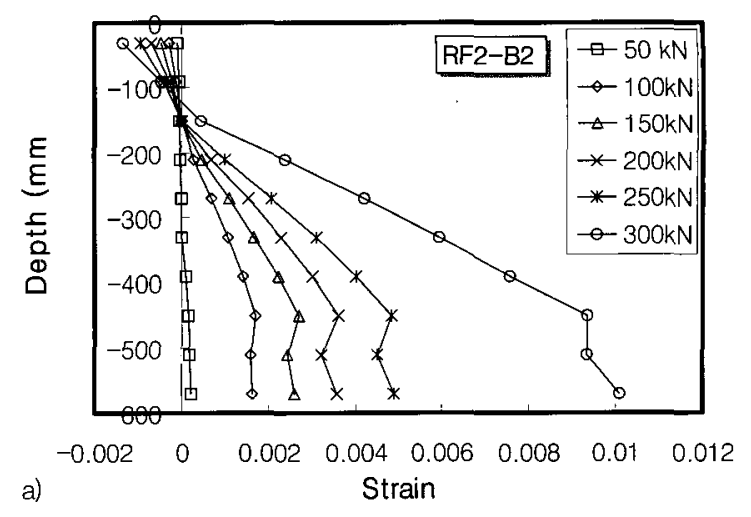

(a) RF2-B2

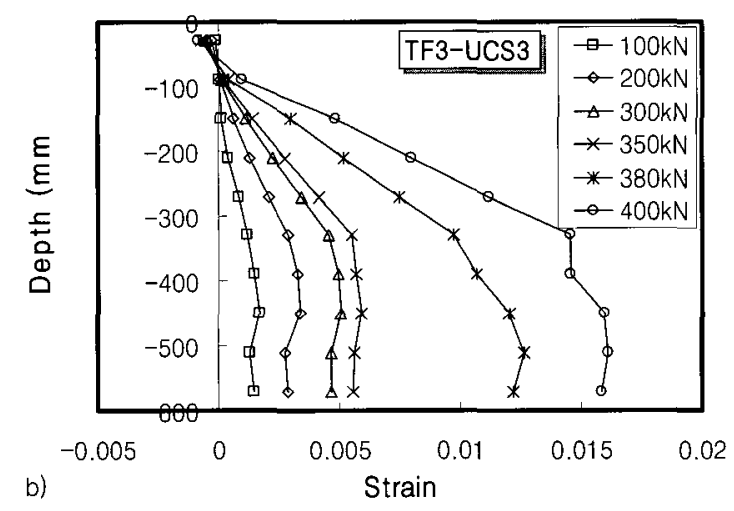

(b) TF3-UCS3

Fig. 7 Sectional strain gradients

For this reason, we apply the processes as shown in (a) (d) to obtain the real strength increments by the CFS strengthening. The process of calculation is as follows.

(a) Calculate the strength increment $\left(\Delta \mathrm{P}_{\text {cf }}\right)$ between the $\operatorname{maximum} \operatorname{load}\left(\mathrm{P}_{\mathrm{u}}\right)$ and the decreased load $\left(\mathrm{P}_{\mathrm{s}}\right)$ at CFS rupture.

(b) Calculate the moment increment $\left(\Delta \mathrm{M}_{\mathrm{cf}}\right)$ from (a).

(c) Calculate the tensile stress $\left(f_{c f}\right)$ at CFS rupture by sectional analysis.

(d) Calculate the strain ( $\left.\varepsilon_{\mathrm{cf}-\mathrm{cal}}\right)$ by dividing the tensile stress of (c) by the elasticity modulus of CFS.

The calculated characteristic values by the procedures mentioned above are shown in Table 8. As shown in Table 8 , the ultimate strains calculated following this procedure are almost similar to the measured strains of each specimen. Thus, all the measured data and the test method for strengthening effects by CFRP are considered very reliable.

\subsubsection{Partial strength reduction factor}

The tensile strengths of multi-layer CFS at rupture are shown in Figs. 8 and 9 obtained from the full-scale RC beam tests as well as the material tests. As shown in Figs. 8 
and 9, the tensile strengths of CFS at rupture were decreased generally as the number of layers was increased. The declining rate is also reduced and converges to a certain value. On the other hands as shown in Fig 9, the tensile strength declining rate of HS300 CFS at rupture doesn't converge to a certain value. However, there is little possibility to be strengthened by more than 3 layers of HS300 CFS, the test results within this limit will be sufficient to understand the strength declining rate of CFS.

The HS300 CFS was reported to have the same physical properties compared with those of the HS200 CFS except the fiber thickness is $0.167 \mathrm{~mm}$, which is about 1.5 times that of HS200 CFS. However, according to the test results, the tensile strength of HS300 CFS was less than that of the HS200 CFS at the same number of layer. It indicates that the strength reduction characteristics can be varied not only by the number of layer but also by the fiber weight per unit area. Thus the simple assumption that the tensile strength of HS300 CFS is 1.5 times higher than that of HS200 CFS must be reviewed.

As shown in Figs. 8 and 9, the tensile strengths of multilayer CFS at rupture were decreased linearly as the number of CFS layer was increased and converge to a certain value. These strength reduction characteristics for the multi-layer CFS can be denoted as follows based on the linear regression analysis obtained from the full-scale RC model tests.

$$
\Psi=\boldsymbol{\Phi}-(\mathrm{n}-1) \times 0.11 \geq 0.5
$$

Where, $\Psi$ : partial strength reduction factor of CFS

$\Phi$ : initial value by different fiber weight

(HS200 $=0.83$, HS300 $=0.70$ )

$\mathrm{n}:$ the number of CFS layer

The tensile strengths of the multi-layer CFS observed in

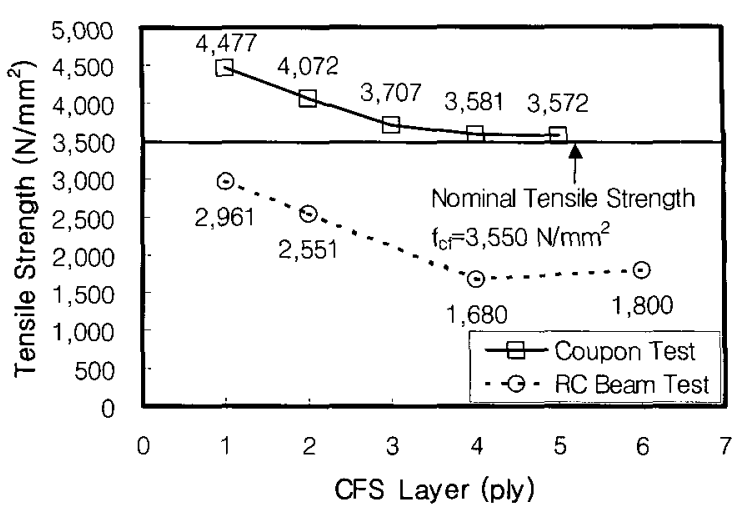

Fig. 8 Tensile strength of the multi-layer HS200 CF sheets

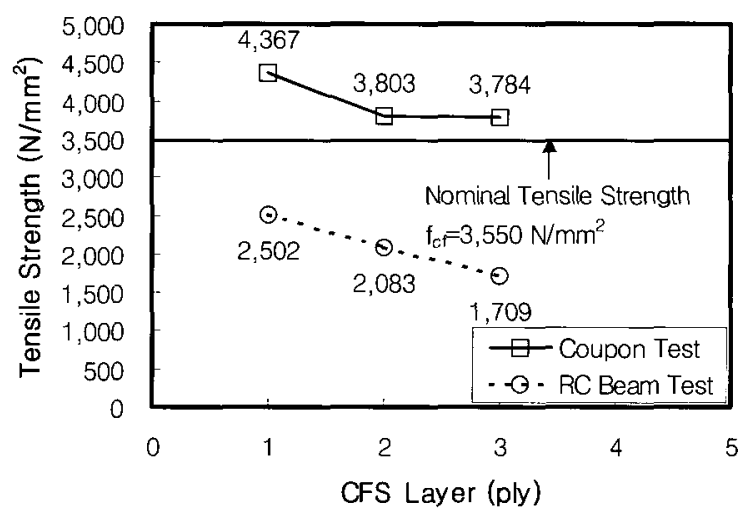

Fig. 9 Tensile strength of the multi-layer HS300 CF sheets

all the strengthened specimens are quite less than the specified tensile strength by manufactures, $f_{c f n}=3,550 \mathrm{~N} / \mathrm{mm}^{2}$. The ACI Committee 440 recommends the partial strength reduction factor as 0.85 for the flexural members and AIK (Architectural Institute of Korea) recommends the strength reduction factor as 0.7 . But they seem to overestimate the

Table 8 Tensile stress and measured strain of CF sheets

\begin{tabular}{|c|c|c|c|c|c|c|c|c|c|c|}
\hline Specimen & Layer(ply) & $\mathrm{P}_{\mathrm{u}}(\mathrm{kN})$ & $P_{s}(k N)$ & $\Delta \mathrm{P}_{\mathrm{cf}}(\mathrm{kN})$ & $\Delta \mathrm{M}_{\mathrm{cf}}(\mathrm{kN} \cdot \mathrm{m})$ & $\Delta T_{c f}(k N)$ & $\mathrm{f}_{\mathrm{cr}}(\mathrm{MPa})$ & $\varepsilon_{c f-c a l}(\mu)$ & $\varepsilon_{\text {cf-sg }}(\mu)$ & $\mathrm{f}_{\mathrm{cf}} / \mathrm{f}_{\mathrm{cfn}}$ \\
\hline RF2-B2 & 2 & 357.1 & 294.0 & 63.1 & 94.7 & 169.9 & 2,551 & 10,856 & 9,796 & 0.72 \\
\hline TF4-UCB2 & 4 & 410.7 & 325.1 & 85.6 & 128.4 & 223.8 & 1,680 & 7,150 & 6,998 & 0.47 \\
\hline TF6-UCB3 & 6 & 478.5 & 341.6 & 136.9 & 205.4 & 359.6 & 1,800 & 7,659 & 7,436 & 0.51 \\
\hline RF1-UCS3 & 1 & 340.2 & 293.5 & 46.7 & 70.1 & 125.4 & 2,502 & 10,647 & 12,395 & 0.70 \\
\hline RF2-UCS3 & 2 & 372.0 & 295.0 & 77.0 & 115.5 & 208.7 & 2,083 & 8,862 & 10,423 & 0.59 \\
\hline TF3-UCS3 & 3 & 443.1 & 345.0 & 98.1 & 147.2 & 256.8 & 1,709 & 7,271 & 7,730 & 0.48 \\
\hline \multicolumn{11}{|c|}{$\begin{array}{l}\mathrm{P}_{\mathrm{u}}: \text { Maximum load before } \mathrm{CFS} \text { rupture } \\
\Delta \mathbf{P}_{\mathrm{cf}}: \text { Load difference before and after CFS rupture } \\
\mathrm{T}_{\mathrm{cf}}: \text { Tensile force of CFS calculated as } \Delta \mathrm{M}_{\mathrm{cf}} / \mathrm{Z} \\
\varepsilon_{\mathrm{cf}-\mathrm{cal}}: \text { Tensile strain of CFS calculated as } \mathrm{f}_{\mathrm{cf}} / \mathrm{E}_{\mathrm{f}}\end{array}$} \\
\hline
\end{tabular}


tensile strength of the multi-layer CFS in the case of being strengthened by 3 layers or more. Therefore, to ensure the safety of strengthened members by the multi-layer CFS, it is needed to review the partial strength reduction factor for the multi-layer CFS. The partial strength reduction factor suggested in this study can be used as the strength reduction factor of multi-layer CFS.

\section{Conclusions}

The strength reduction characteristics of multi-layer CFS were investigated through the material and structural tests in this study. Based on the test results, the following conclusions were drawn.

1) The tensile strength of CFS at rupture has the tendency to be decreased as the number of layer was increased in both cases of HS200 and HS300 CFS.

2) The strength reduction characteristics can be varied not only by the number of layer but also by the fiber weight per unit area.

3) The tensile strengths of CFS at rupture obtained from the full-scale model tests are remarkably less than the specified tensile strength by manufactures compared with the nominal tensile strength obtained from material test.

4) The partial strength reduction factors are suggested in this study considering the number of multi-layer CFS and fiber weight per unit area.

\section{Acknowledgement}

This paper is a part of the research project named "Performance Evaluation of Repairing and Strengthening for RC Building Structure." Support for this research by ' 99 National R\&D Program for Construction Technology under Grant No. R\&D/99-building07 is greatly acknowledged.

\section{References}

1. Sin, S.-W., "Effect of anchorage type of CFS on flexural behavior of RC beam ", Journal of Korea institute for Structural Maintenance Inspection, Vol.2 No.2, 1998, pp.202 208.

2. Lee, Y.-T., "Improvement of flexural capacity of reinforced concrete beams reinforced by CFS," Journal of Korea institute for Structural Maintenance Inspection, Vol.3 No.3, 1999, pp. 203 211.

3. Lee, H.-S., "Strength of material of CFS," Journal of Korea Concrete Institute, Vol. 10 No.2, 1998, pp.803 808.

4. Architectural Institute of Korea, "Repairing and strengthening of concrete structure," Technical Report ATR 97-1, 1997, pp. 127 131.

5. You, Y.-C., Kim, K.-H., Choi, K.-S., "Performance Evaluation of Repair and Strengthening for RC Building Structure," Korea Institute of Construction Technology, 2001, pp.220 261.

6. 建築研究振興協會, “炭素纖維シート補强工事の材料と工 法”, 建築研究振興協會, 1997, pp.23 26.

7. 日本コンクリート工學協會, “炭素纖維シートによるコン クリート構造物の補 修·補强設計·施工マニュアル(案) 橋 脚編”, 連續纖維補强コンクリート研究委員會報告集, 1997, pp.122 124.

8. ACI Committee 440, "Guide for the Design and Construction of Externally Bonded FRP System for Strengthening Concrete Structure," American Concrete Institute, 2002, pp. $21 \sim 25$. 